\title{
Personer med demens kan ha nytte av tilpasset kognitiv atferdsterapi
}

\section{Personer med demens i tidlig fase kan ha ulik sykdomsinnsikt og motivasjon til å delta i samtaler med terapeut. En manualbasert intervensjon kan hjelpe med å finne et relevant mål for terapien ut fra personens livssituasjon.}

\section{FORFATTERE}

Helen Staubo

Spesialsykepleier i psykisk helse

Alderspsykiatrisk poliklinikk, Oslo universitetssykehus HF, Ullevål

\author{
Nina Misvær \\ Førstelektor \\ Institutt for sykepleie og helsefremmende arbeid, Høgskolen i Oslo og Akershus
}

\section{Johanne Bjørnstad Tonga}

Psykolog og ph.d.-stipendiat

Alderspsykiatrisk poliklinikk, Oslo universitetssykehus HF, Ullevål og Nasjonalforeningen for folkehelsen

\section{Kari Kvigne}

sykepleier og 1.-amanuensis

Ingun Ulstein

Psykiater og overlege

Hukommelsesklinikken, Oslo universitetssykehus HF, Ullevål

\section{NøKKELORD}

Demens, Kognitiv atferdsterapi, Livskvalitet, Pårørende, Casestudie

\section{SAMMENDRAG}

Bakgrunn: Studier viser at psykoterapi kan bidra til å bevare funksjonsnivå og livskvalitet hos personer med demens.

Hensikt: Denne casestudien er en del av KORDIAL-studien. Hensikten med denne randomiserte kontrollerte intervensjonsstudien, var å vurdere hvordan en intervensjon påvirket deltakernes hverdagsliv og livskvalitet. Videre ønsker vi å beskrive samhandlingen mellom deltakerne og terapeuten.

Metode: Intervensjonen var basert på kognitiv atferdsterapi som fokuserte på meningsfylte aktiviteter for å modifisere depresjon, hukommelseshjelpemidler og reminisens. Intervensjonen besto av elleve ukentlige møter. Vi førte loggnotater fra hvert møte. Loggnotatene ble analysert etter prinsippene som er formulert i Graneheim og Lundmans kvalitative innholdsanalyse. 
Resultat: Den ene personen forsto ikke hensikten med intervensjonen og klarte dermed ikke å gjøre nytte av verktøyene. Den andre var motivert for å lære og erfarte hva hun kunne gjøre for å ha en meningsfylt hverdag, noe som blant annet bidro til at hun var mindre nedstemt.

Konklusjon: Sykdomsinnsikt og motivasjon er faktorer som må vurderes ved valg av terapeutisk tilnærming overfor personer med demens i tidlig sykdomsfase. Den ene personen hadde muligens hatt bedre utbytte av en annen tilnærming. For den andre personen hadde intervensjonen god innvirkning på hverdagsliv og livskvalitet. Pårørendes deltakelse syntes å være positiv og til støtte for personen med demens.

I 2012 var det om lag 77000 personer med demenssykdom i Norge. De fleste var over 70 år (1). Antall personer som rammes, er økende og representerer en global utfordring. I $2030 \mathrm{er}$ antallet demenssyke på verdensbasis estimert til 65,7 millioner mennesker, og det forventes at antallet fordobles hvert tjuende år (2).

Det vanligste symptomet er svekket hukommelse, særlig for nyere informasjon. Dagligdagse aktiviteter som å handle og betale regninger påvirkes gradvis (3). I dag finnes ingen kurativ, medikamentell behandling, og tilgjengelige antidemenslegemidler har kun symptomatisk og forbigående effekt (4).

Resultater fra en oversiktsartikkel viser at ikke-medikamentelle terapier kan være realistiske og Iønnsomme behandlingsalternativer for personer med Alzheimers sykdom (5). Kognitiv trening og stimulering, $\varnothing$ ving på dagliglivets gjøremål og utføring av meningsfylte aktiviteter ga både personer med demens og deres pårørende økt livskvalitet. Ved at pårørende fikk kunnskap og støtte, kunne institusjonalisering av personen med demens utsettes (5).

\section{HENSIKT MED STUDIEN}

En tysk multisenterstudie, CORDIAL (Cognitive Rehabilitation and Cognitive-behavioural Treatment for Early Dementia in Alzheimer Disease), hadde lovende resultater for personer med Alzheimer (6). Resultatene viste at intervensjonene hadde effekt på depresjon, innsikt og livskvalitet.

Den tyske CORDIAL-studien danner utgangspunktet for den norske KORDIAL-studien, en manualbasert, randomisert kontrollert intervensjonsstudie som inkluderer 200 hjemmeboende personer med demens i tidlig sykdomsfase og deres pårørende.

I tilknytning til KORDIAL-studien gjennomførte vi en kvalitativ delstudie med to personer og deres pårørende. Hensikten var å vurdere den manualbaserte intervensjonens innvirkning på deltakernes hverdagsliv og livskvalitet. Hensikten var også å beskrive samhandlingen mellom personen med demens, personens pårørende og terapeuten.

\section{STUDIENS FORSKNINGSSPøRSMÅL}

Med utgangspunkt i hensikten med delstudien vår ønsket vi å finne ut følgende:

- På hvilken måte påvirket intervensjonen deltakernes hverdagsliv og livskvalitet, og hvordan var samhandlingen mellom dem og terapeuten?

\section{METODE}


I tråd med studiens hensikt og forskningsspørsmål brukte vi en hermeneutisk tilnærming som er forankret i kvalitativ forskningstradisjon der det siktes mot å forstå, og der målet er å beskrive (7). Derfor valgte vi casestudie, som er relevant der man ønsker å forklare, beskrive og gå i dybden av et fenomen (8).

Casestudier kan være beskrivende, tolkende eller vurderende, eller de kan ha med alle tre elementene samtidig, slik som i studien vår. I den beskrivende delen er deltakerens perspektiv fremtredende. Den tolkende delen har til hensikt å illustrere, støtte, utfordre og utvikle eksisterende teori. Vurderingsdelen fokuserer mer på forskerens vurderinger med utgangspunkt i teorier (9).

Vi supplerte studien ved å bruke to kvantitative måleinstrumenter som inngår i hovedstudien: Montgomery and Åsberg Depression Rating Scale (MADRS) (10), som kartlegger depressive symptomer, og Quality of Life in Alzheimer's Disease Scale (QOL-AD) (11), som vurderer livskvalitet. Måleinstrumentene ble besvart før og etter intervensjonen for å se eventuell effekt.

\section{INKLUSJONS- OG EKSKLUSJONSKRITERIER}

Personene vi inkluderte i studien, måtte være diagnostisert med Alzheimers sykdom i løpet av de siste tolv månedene. Videre måtte de skåre minst 20-30 poeng på den kognitive testen Mini Mental Status Examination (MMSE) (12) og være hjemmeboende med minimum ukentlig kontakt med pårørende. Eksklusjonskriterier var pågående psykoterapi og alvorlig somatisk eller psykisk sykdom som tilleggsdiagnose (tabell 1).

Rekrutteringen foregikk ved en hukommelsesklinikk ved et universitetssykehus i 2013.

Hukommelsesklinikken henviste de inkluderte personene til en alderspsykiatrisk poliklinikk for å gjennomføre intervensjonen der. 


\section{Tabell 1: Biografiske data}

\section{Bakgrunn}

\section{Knut}

\section{2 år gammel}

Gift

Hjemmeboende sammen med ekte-

fellen

Ti års utdanning

Diagnose: Alzheimers sykdom

Åse
70 år gammel
Gift
Hjemmeboende sammen med ekte-
fellen
Ti års utdanning
Diagnose: Alzheimers sykdom

\section{BESKRIVELSE AV INTERVENSJONEN}

I intervensjonen brukte terapeuten en manual (13) som inneholdt temaer for elleve ukentlige møter (tabell 2). Utgangspunktet var å finne et relevant mål for terapien ut fra personens livssituasjon og utfordringer i hverdagen. Manualen inneholdt også arbeidsark til å bruke i møtene og hjemme. Terapeuten tilpasset terapien til personens funksjon og behov.

«Hensikten med intervensjonen var å opprettholde pasientens mestring i hverdagen og redusere depresjonssymptomer.» 
hverdagen og redusere depresjonssymptomer. Personen registrerte hvordan daglige aktiviteter påvirket sinnsstemningen i en ukeplan, og ble dermed mer bevisst og kunne velge meningsfylte aktiviteter som virket positivt på humøret.

Et av arbeidsarkene som ble brukt som hjelpemiddel, var en liste med lystbetonte aktiviteter. I tillegg omfattet intervensjonen at terapeuten tok i bruk hukommelseshjelpemidler, som avtalebok, biografiarbeid og fotoalbum. Pårørende deltok i annethvert møte for å få kunnskap om og støtte opp under terapien. Når personen kom alene, fikk vedkommende med et pårørendebrev som inneholdt orientering om hvilket tema de hadde gjennomgått.

Tabell 2: Oversikt over temaene i intervensjonen med utgangspunkt i manualen for KORDIAL-studien

\begin{tabular}{|c|c|c|}
\hline \multirow[t]{2}{*}{ Modul 1} & Innføringsmodul & \\
\hline & 1. $m \varnothing t e^{*}$ & Innføring i programmet og målsetting for behandlingen \\
\hline \multirow[t]{3}{*}{ Modul 2} & Regelmessige aktiviteter & \\
\hline & 2. $\mathrm{m} \varnothing \mathrm{te}$ & Ukeplan \\
\hline & 3. møte* & Etablering av lystbetonte aktiviteter \\
\hline \multirow[t]{3}{*}{ Modul 3} & Hukommelseshjelpemidler & \\
\hline & 4. møte & Innføring i bruk av avtalebok \\
\hline & 5. møte* & Hvordan bruke avtalebok i fellesskap med pårørende \\
\hline \multirow[t]{3}{*}{ Modul 4} & Hukommelsesproblemer i hverdagen & \\
\hline & 6. møte & Avlastning gjennom vaner \\
\hline & 7. $m \varnothing t e^{*}$ & Hvordan løse hukommelsesproblemene i fellesskap \\
\hline \multirow[t]{3}{*}{ Modul 5} & Gode minner & \\
\hline & 8. møte & Personlige gode minner \\
\hline & 9. $m \varnothing t e^{*}$ & Felles biografiarbeid sammen med pårørende \\
\hline \multirow[t]{3}{*}{ Modul 6} & Avslutningsmodul & \\
\hline & 10. møte & Utbytte av treningen i forhold til målsettingen \\
\hline & 11. møte* & Felles tilbakeblikk og planlegging for tiden framover \\
\hline
\end{tabular}

*Pårørende var til stede

\section{DATAINNSAMLING}

Terapeuten skrev journalnotater og loggnotater etter hvert møte. Loggnotatene utgjør hovedtyngden av dataene i studien og inneholder temaet for møtet samt beskrivelse av samspillet mellom personen med demens, de pårørende og terapeuten. De inneholder også reaksjoner og utsagn fra personen og pårørende samt terapeutens egne observasjoner og refleksjoner. Loggnotatene utgjør 31 maskinskrevne sider.

\section{ANALYSE}

Vi analyserte loggnotatene i henhold til Graneheim og Lundmans metode for innholdsanalyse (14). Metoden består av å lese teksten flere ganger, finne meningsbærende enheter og kondensere meningsbærende enheter. Videre omfatter den en abstraheringsprosess der underkategorier, kategorier og temaer opprettes. Analysen ble foretatt av førsteforfatteren, som også var terapeuten.

\section{ETIKK}

Studien ble godkjent av Regionale komiteer for medisinsk og helsefaglig forskningsetikk (REK) i Helse Sør- $\varnothing$ st gjennom KORDIAL-studien. Deltakerne ga informert samtykke til å delta. De samtykket også til at materialet kunne brukes i artikkelen. De fikk informasjon om retten til å trekke seg underveis. Personene i studien er anonymiserte. 
Knut merket at han hadde redusert hukommelse fire til fem år før intervensjonen. Korttidshukommelsen, innlærings- og organiseringsevnen var svært dårlig. Han trengte også hjelp til blant annet å kle på seg og til å dele opp maten.

\section{«Knut mente selv at han klarte seg bra, men var ifølge kona passiv og ville helst sitte i stolen og sove.»}

Knut mente selv at han klarte seg bra, men var ifølge kona passiv og ville helst sitte i stolen og sove. Han var klar over at hukommelsen var nedsatt, men opplevde det ikke som et problem. Knut følte seg ikke deprimert og syntes livet var greit. Kona fortalte at de hadde program hver dag. De gikk turer, var på eldresenteret og i butikken.

Tabell 3: Knut: Forståelse av situasjonen, samhandling i intervensjonen, innvirkning på hverdagsliv og livskvalitet

\begin{tabular}{|c|c|c|c|}
\hline $\begin{array}{l}\text { Knuts forståelse/ } \\
\text { situasjon }\end{array}$ & $\begin{array}{l}\text { Samhandlingen i } \\
\text { intervensjonen }\end{array}$ & $\begin{array}{l}\text { Innvirkning på hver- } \\
\text { dagsliv og livskvalitet }\end{array}$ & Resultat tester \\
\hline $\begin{array}{l}\text { Forsto ikke hensikten med } \\
\text { intervensjonen }\end{array}$ & $\begin{array}{l}\text { Å motivere Knut for } \\
\text { deltakelse }\end{array}$ & Ikke nevneverdige endringer & $\begin{array}{l}\text { Før intervensjonen: } \\
\text { MADRS: } 6 / 60\end{array}$ \\
\hline $\begin{array}{l}\text { Fornøyd med livet } \\
\text { som det var }\end{array}$ & $\begin{array}{l}\text { A finne fram til meningsfylte } \\
\text { aktiviteter }\end{array}$ & $\begin{array}{l}\text { Knut og kona hadde daglig } \\
\text { program }\end{array}$ & QOL-AD: $45 / 52$ \\
\hline $\begin{array}{l}\text { Trengte ikke huske, } \\
\text { for kona husket }\end{array}$ & $\begin{array}{l}\text { Å skape rutiner for Knut } \\
\text { og kona }\end{array}$ & $\begin{array}{l}\text { Kona fikk bekreftet at hun } \\
\text { allerede gjorde mye bra for } \\
\text { Knut }\end{array}$ & $\begin{array}{l}\text { Etter intervensjonen: } \\
\text { MADRS: } 2 / 60 \\
\text { QOL-AD: } 41 / 52\end{array}$ \\
\hline $\begin{array}{l}\text { Ikke motivert for arbeidsark/ } \\
\text { hjemmeoppgaver }\end{array}$ & $\begin{array}{l}\text { Avtalebok - et fellesprosjekt } \\
\text { Merarbeid eller hjelp for kona? } \\
\text { Å styrke Knuts identitetsfølelse }\end{array}$ & $\begin{array}{l}\text { Pårørendebrevene var til god } \\
\text { hjelp for kona } \\
\text { Ser i album jevnlig }\end{array}$ & \\
\hline
\end{tabular}

MADRS = Montgomery and Åsberg Depression Rating Scale

$\mathrm{QOL}-\mathrm{AD}=$ Quality of Life in Alzheimer's Disease Scale

\section{INNVIRKNING PÅ HVERDAGSLIV OG LIVSKVALITET}

For Knut førte intervensjonen ikke til endringer, noe som gjenspeiles i MADRS (10) og QOL-AD (11) (tabell 3). Ektefellen syntes det var fint å høre at hun allerede gjorde mye bra for mannen sin, og få bekreftet at det var naturlig å bli både irritert og lei av og til.

\section{SAMHANDLINGEN}

Fordi Knut ikke syntes det var noe problem med nedsatt hukommelse, ble det vanskelig å følge manualen som intervensjonen tok utgangspunkt $i$. Terapeuten fant det hensiktsmessig at ektefellen deltok på alle møtene. De kom frem til målsettingen i fellesskap: «å opprettholde nåværende funksjonsnivå».

Knut greide ikke å registrere gjøremål i ukeplanen for å bli mer bevisst på hva han syntes var meningsfylt. Da terapeuten snakket om slektsforskning og tegning som, ifølge kona, hadde opptatt ham tidligere, viste han verken interesse for det eller vemod over at det ikke lenger 
gledet ham. Han sa selv at han var ferdig med det: "Det er en tid for alt.» Han viste heller ingen interesse for arbeidsarkene. Da terapeuten spurte om han helst ville slutte å komme, svarte han: «Tvert imot, dette er da så hyggelig.»

Knut stilte seg uforstående til å bruke felles avtalebok, selv om ektefellen syntes det hadde vært fint fordi han stadig spurte om igjen. Han mente selv han ikke trengte noen avtalebok, fordi «kona husker så godt». Da terapeuten foreslo å gjøre avtaleboken til et eksperiment og fellesprosjekt, ønsket han å prøve. Mot slutten av intervensjonen hadde de gjort noen positive erfaringer med å bruke felles avtalebok, men noen ny vane var ikke etablert.

Til møtet om personlige, gode minner hadde de med fotoalbumer fra Knuts oppvekst. De så også ofte i albumer hjemme, noe som vekket gode minner og engasjement hos Knut.

\section{CASE 2}

Åse begynte å få dårligere hukommelse for fem-seks år siden. Hun klarte seg bra i det daglige, var glad i husarbeid og laget fortsatt mat, men mistet lett oversikt over tidspunkter. Hun var av og til nedstemt, ifølge henne selv og ektefellen, men sosial og glad i samvær med familie og venner.

Tabell 4: Åse: Forståelse av situasjonen, samhandling i intervensjonen, innvirkning på hverdagsliv og livskvalitet

\begin{tabular}{|c|c|c|c|}
\hline $\begin{array}{l}\text { Åse forståelse/ } \\
\text { situasjon }\end{array}$ & $\begin{array}{l}\text { Samhandlingen i } \\
\text { intervensjonen }\end{array}$ & $\begin{array}{l}\text { Innvirkning på hver- } \\
\text { dagsliv og livskvalitet }\end{array}$ & Resultat tester \\
\hline $\begin{array}{l}\text { Gledet seg til å starte } \\
\text { intervensjonen }\end{array}$ & Anerkjennelse av Åses følelser & $\begin{array}{l}\text { Bedre kommunikasjon } \\
\text { med ektefelle }\end{array}$ & $\begin{array}{l}\text { Før intervensjonen: } \\
\text { MADRS: } 18 / 60\end{array}$ \\
\hline $\begin{array}{l}\text { Opplevde nedsatt hukommelse } \\
\text { som et problem }\end{array}$ & $\begin{array}{l}\text { Bidra til at Åse finner mestrings- } \\
\text { strategier som fungerer }\end{array}$ & $\begin{array}{l}\text { Skrive ned stikkord fra } \\
\text { samtaler, noe som hjelper }\end{array}$ & QOL-AD: $32 / 52$ \\
\hline $\begin{array}{l}\text { som et problem } \\
\text { Kunne lett føle seg krenket }\end{array}$ & $\begin{array}{l}\text { Bidra til at Åse innarbeider } \\
\text { rutiner som blir til vaner }\end{array}$ & $\begin{array}{l}\text { samtaler, noe som hjelper } \\
\text { henne å huske }\end{array}$ & $\begin{array}{l}\text { Etter intervensjonen: } \\
\text { MADRS: } 4 / 60 \\
\text { QOL-AD: } 39 / 52\end{array}$ \\
\hline $\begin{array}{l}\text { Følte seg usikker, redd for } \\
\text { à gjøre feil }\end{array}$ & $\begin{array}{l}\text { Bidra til at Åse styrker sitt egen- } \\
\text { verd og sin identitetsfølelse }\end{array}$ & $\begin{array}{l}\text { Mer forutsigbarhet } \\
\text { og større trygghet }\end{array}$ & \\
\hline $\begin{array}{l}\text { Ønsket å ha det lettere i hverda- } \\
\text { gen, unngå «depping» }\end{array}$ & & $\begin{array}{l}\text { Ser ofte i album sammen } \\
\text { med ektefelle }\end{array}$ & \\
\hline $\begin{array}{l}\text { Motivert for å lære felles bruk av } \\
\text { avtalebok }\end{array}$ & & & \\
\hline
\end{tabular}

\section{INNVIRKNING PÅ HVERDAGSLIV OG LIVSKVALITET}

Åse mente at intervensjonen hadde en positiv virkning på nedstemtheten, noe som vises ved at MADRS (10) gikk ned fra 18/60 til 4/60 i løpet av intervensjonen (tabell 4). Livskvaliteten, QOL-AD (11), gikk litt opp, noe som kan tyde på at intervensjonen hadde positiv innvirkning.

Åse hadde god nytte av felles avtalebok. Ved at kommunikasjonen med ektefellen ble bedre, følte hun seg mer avslappet og ikke så redd for å gjøre feil. Ektefellen uttrykte at møtene var meningsfylte, og det de hadde lært, bidro til å gjøre dagliglivet enklere for dem begge.

\section{SAMHANDLINGEN}

Åse gledet seg til å komme i gang. Hun sa raskt at problemet hennes var redusert hukommelse og gjentakende spørsmål. Hun formulerte selv følgende målsetting: «å ha et jevnere humør og unngå depping». Ektefellen syntes det var utfordrende at kona ikke husket noe fra viktige samtaler de nylig hadde hatt.

Åse uttrykte at hun følte seg dum når hun merket at mannen ble utålmodig eller irritert. 
Dette var sårt for dem begge. Hun sa at hun kunne trengt litt ekstra tid og noen stikkord fra mannen fra samtalene. Denne strategien utforsket de sammen og fant en bedre kommunikasjonsform.

Åse merket at meningsfylte aktiviteter, som for eksempel enkelt husarbeid, virket positivt på humøret. Hjemmeoppgavene, som var en del av intervensjonen, bevisstgjorde henne på hva hun kunne gjøre for å komme i bedre humør. Hun og ektefellen fant ut hvordan de ville bruke felles avtalebok. Hun var ofte litt nedstemt om morgenen fordi hun ikke visste hva hun skulle bruke dagen til.

Da de sammen begynte å skrive i avtaleboken at hun skulle vaske tøy, stryke eller se et TV-program, opplevde hun forutsigbarhet og dermed trygghet fordi, som hun uttrykte det: «Da vet jeg hva jeg skal gjøre.» Det var også viktig å skrive ned tidspunktet for når ektefellen kom hjem og hun skulle lage middag.

De innarbeidet rutiner for fast plass til nøkler, klokke og veske, som også gjorde hverdagen mer forutsigbar og førte til at hun ble mindre urolig. Åse husket mye fra fotografiene de hadde med til biografiarbeidet, og det gledet både henne og ektefellen.

\section{DISKUSJON}

Hensikten med studien vår var å vurdere den manualbaserte intervensjonens innvirkning på deltakernes hverdagsliv og livskvalitet. Vi ville også beskrive samhandlingen mellom personen med demens, dens pårørende og terapeuten.

\section{INNVIRKNING PÅ HVERDAGSLIV OG LIVSKVALITET}

Målsettingen for Knut var «å opprettholde nåværende funksjonsnivå». For ham hadde intervensjonen liten innvirkning på hverdagsliv og livskvalitet, noe som samsvarer med skåren til måleinstrumentene MADRS og QOL-AD, der vi så lite endring. Ifølge Knut fikk han en følelse av å kunne bidra ved å bli inkludert i studien.

Fleksibilitet og tilpasning av manualen for å kunne møte individuelle behov er vesentlig og i samsvar med det som er beskrevet av Tonga og medarbeidere (15). For ektefellen inneholdt pårørendebrevene nyttig informasjon, og gjennom å delta i intervensjonen fikk hun bekreftet at hun gjorde mye riktig og godt for Knut.

Åses målsetting var «å ha et jevnere humør og unngå depping». Målsettingen førte til at kommunikasjonen med ektefellen ble endret, noe som gjorde at hun ikke var så redd for å gjøre feil. Hun følte at han så henne på en annen måte enn før. I lys av Antonovskys teori kan dette oppfattes som at hun fikk en følelse av å forstå og håndtere situasjonen (16).

Forståelsen kan bidra til mestring, helse og velvære og dermed bedre livskvalitet, noe som også indikeres i hennes QOL-AD-skår. Hverdagen ble mer forutsigbar ved at de innarbeidet felles avtalebok. Det førte til at hun var mindre nedstemt, som samsvarte med hennes MADRS-skår. Skåren viste en reduksjon i depressive symptomer.

I henhold til funn i en internasjonal studie kan etablerte psykologiske modeller som kognitiv atferdsterapi redusere depressive symptomer hos personer med demens (17). Studien konkluderer med at psykologiske intervensjoner har potensial til å øke personens følelse av velvære. Gleden ved å se i fotoalbum var en ny erfaring for Åse og ektefellen, og de ønsket å gjøre mer av det.

\section{SAMHANDLINGEN}

Fra terapeutens perspektiv ble samhandlingen med Knut utfordrende da han ikke mente selv 


\section{«Knut viste ingen interesse for å prøve noe av det som ble foreslått i henhold til manualen.»}

Knut viste ingen interesse for å prøve noe av det som ble foreslått i henhold til manualen. Han virket passiv og initiativløs, som er en atferdsendring som hyppig inntreffer ved demens i tidlig fase (18). Atferden hans kan forstås som en benektelse av sykdommen (19) for å prøve å dekke over at han var redd for ikke å mestre hverdagen (20).

Atferden kan også komme av manglende sykdomsinnsikt, som ofte forekommer ved demens i tidlig fase (3). I Knuts tilfelle ville muligens en annen form for behandling vært mer egnet, slik som kognitiv stimulering, som kan redusere apati ved demenssykdom (21).

\section{KOMPENSERINGSFASEN}

Det positive bildet Knut ga av situasjonen sin, kunne være et uttrykk for det Engedal kaller kompenseringsfasen (3). Fasen er blant annet preget av redusert hukommelse og problemer med å relatere hendelser i riktig tidsperspektiv, som for eksempel da Knut hevdet at han fortsatt skrev avtaler på bordkalenderen.

Funn i en internasjonal studie viser at det å leve med sykdommen ofte ble presentert som en positiv historie ved at personene med demens la vekt på det de mestret, og formidlet at de var tilfredse med livet (22). Dette gjenkjenner vi hos Knut, som i tillegg til å fremheve hvor godt han hadde det, fortalte om ting han fortsatt gjorde. Han leste bøker, gjorde småting i huset og gikk turer alene. Ifølge ektefellen stemte ikke dette.

Knut hadde det Næss (23) betegner som en grunnstemning av glede ved at han var fornøyd med livet. Denne gleden ble også avspeilet i MADRS- og QOL-AD-skåren.

\section{MINNEARBEIDET ENGASJERTE}

Knut ble irritert på kona da hun prøvde å motivere ham fordi han ikke forsto hensikten verken med arbeidsarkene eller forsøkene på å innføre felles avtalebok. Hun syntes situasjonen var belastende inntil terapeuten foreslo å kalle disse hjemmeoppgavene for et eksperiment og fellesprosjekt. Dette appellerte også til Knut, som ble positiv til å prøve.

Minnearbeidet skapte et engasjement hos Knut samtidig som det ga terapeuten et inntrykk av hvilken person Knut hadde vært, samt hva hans verdier og livsløp hadde vært. Minnearbeidet syntes å bygge opp Knuts selvforståelse og identitet, og ga ham gode opplevelser.

Å se i album kan bidra til at gode følelser fra tidligere gjenoppleves her og nå. Det kan dessuten være med på å forsterke selvfølelsen, noe som beskrives som å kjenne seg selv igjen (24), og som er i tråd med Tranvåg og medarbeidere (25). De hevder at det å gi 
oppmerksomhet til demenssykes livshistorie og livsprosjekter, i tillegg bidrar til å fremme deres opplevelse av verdighet i hverdagen. Pårørende bidrar også til å videreføre kontinuiteten i livsløpet til mennesker (26).

\section{KUNNE FøLE SEG KRENKET}

Terapeuten syntes samhandlingen med Åse var fruktbar og mente at intervensjonen egnet seg for henne. Hun var ivrig og interessert i å lære hva som kunne bidra til selvstendighet og en bedre hverdag, blant annet i relasjon til ektefellen. Åse var klar over sin hukommelsessvikt, som i noen sammenhenger gjorde at hun følte seg krenket.

Personer med demens er vare for signaler om manglende aksept og utilstrekkelighet (27). Derfor er behovet for å bli sett og respektert viktig $(28,29)$. Åse devaluerte seg selv for at hun husket dårligere. Slike tanker øker risikoen for depresjon (30).

\section{FøLTE SEG NYTTIGE}

Både Knut og Åse opplevde glede i hverdagen og levde i gode relasjoner, i tråd med Næss (23). Næss hevder at livskvalitet handler om kjærlighet, engasjement, selvrespekt og glede. Begge uttrykte at de følte seg nyttige: Knut ved å støtte kona med armen og bære handleposer - Åse ved å stryke og gjøre husarbeid.

\section{«[Åse] syntes intervensjonen var meningsfull og ble motivert til å bidra aktivt selv.»}

Åse syntes møtene var spennende. Hun likte å få hjemmeoppgaver og syntes det var tilfredsstillende å snakke om hva hun hadde lært når hun kom til neste møte. Hun syntes intervensjonen var meningsfull og ble motivert til å bidra aktivt selv, noe som er sentralt i Antonovskys teori om opplevelse av sammenheng (16).

Antonovsky hevder at vår motstandskraft avhenger av i hvilken grad vi opplever tilværelsen som forståelig, håndterbar og meningsfull. Blant disse er mening den motiverende komponenten, noe som gir motivasjon til endring (16).

\section{STYRKER OG SVAKHETER VED STUDIEN}

Det er viktig å integrere gyldighet og troverdighet i forskningsprosessen, noe som innebærer at alle ledd er gjennomsiktige, åpne og overbevisende (7). En svakhet ved studien kan være dobbeltrollen som terapeut og forsker fordi studien kan bli preget av et subjektivt blikk. Subjektiviteten er moderert ved at medforfatterne var med i refleksjonene i analyseprosessen.

Ved at forskeren også var terapeut observerte hun deltakernes kroppsspråk, som tydeliggjorde deres opplevelse av møtet. Observasjonene var subjektive og kunne av den grunn være unøyaktige. Hvis dialogen i møtene hadde vært registrert digitalt og deretter transkribert, kunne det muligens ha styrket studiens troverdighet ved at ulike forskere fikk tilgang på alt som var sagt. 
Studien omhandler kun to deltakere med ulik grad av kognitiv svikt, som medførte forskjellig tilnærming og nytteverdi av intervensjonen. Kvalitative studier har ikke som mål å generalisere funn. De skal heller utdype og beskrive hva som skjedde, noe som kan være nyttig med tanke på å videreutvikle erfaringer fra denne studien.

En styrke var at kvalitativ metode ble supplert med kvantitative måleinstrumenter for å vurdere om intervensjonen hadde effekt på deltakernes hverdagsliv og livskvalitet. Funnene kan ikke generaliseres, men videre forskning kan se på livskvalitet og tegn på depressive symptomer etter en tilsvarende intervensjon på et større datamateriale.

I tillegg kan fremtidig forskning undersøke hvordan pårørendes situasjon påvirkes av å delta i intervensjonen, og hvorvidt en positiv endring vil kunne medvirke til at personer med demens kan bo hjemme lenger.

\section{KONKLUSJON}

Funn fra denne studien viser at intervensjonen påvirket deltakernes hverdagsliv og deres livskvalitet i ulik grad og på forskjellig måte. Samhandlingen mellom deltakerne og terapeuten ble svært forskjellig avhengig av personens sykdomsinnsikt og motivasjon for å delta.

Knuts liv ble lite påvirket grunnet manglende sykdomsinnsikt. Åse var motivert for å lære og følte at hverdagen ble mer forutsigbar ved å bruke hjelpemidler. Hun ble mindre nedstemt ved å bli bevisst på hva som virket positivt inn på sinnsstemningen, og som bedret kommunikasjonsformen med mannen. Begge ektefellene opplevde at innsatsen deres ble verdsatt, og at de hadde fått større forståelse for hvordan de kunne støtte sine pårørende.

Det er grunn til å tro at ved å kartlegge personer med demens godt, kan man finne ut om denne intervensjonen er egnet. Videre forskning bør kartlegge personen grundigere $f \varnothing r$ inkludering samt unders $\varnothing$ ke hvilken betydning antall møter har for ulike personers utbytte av terapien. Intervensjonen kan også prøves ut i gruppemøter, eventuelt i kombinasjon med individuelle møter.

\section{REFERANSER}

1. Helse - og omsorgsdepartementet. Demensplan 2020. Et mer demensvennlig samfunn. 2015.

2. Prince $M$, Bryce R, Albanese E, Wimo A, Ribeiro W, Ferri CP. The global prevalence of dementia: A systematic review and metaanalysis. Alzheimers \& Dementia 2013;9:63-75.

3. Engedal K. Alderspsykiatri i praksis: lærebok. 2. utg. Tønsberg: Forlaget Aldring og helse; 2008.

4. Birks J. Cholinesterase inhibitors for Alzheimer's disease. Cochrane Database Syst Rev $2006 ; 25(21)$.

5. Olazaran J, Reisberg B, Clare L, Cruz I, Pena-Casanova J, del Ser T et al. Nonpharmacological therapies in Alzheimer's disease: A systematic review of efficacy. Dementia and Geriatric Cognitive Disorders 2010;30:161-78.

6. Kurz A, Thöne-Otto A, Cramer B, Egert S, Frölich L, Gertz H et al. CORDIAL: Cognitive rehabilitation and cognitive-behavioral treatment for early dementia in Alzheimer disease. Alzheimer Disease and Associate Disorders 2012;26:246-52. 
7. Malterud K. Kvalitative metoder i medisinsk forskning. En innføring. 3. utg. Oslo: Universitetsforlaget; 2013.

8. Yin RK. Case study research. Design and methods. Thousand Oaks, California: SAGE publications; 2014.

9. Postholm MB. Kvalitativ metode. En innføring med fokus på fenomenologi, etnografi og kasusstudier. 2. utg. Oslo: Universitetsforlaget; 2011.

10. Montgomery SA, Åsberg M. A New depression scale designed to be sensitive to change. British Journal \& Psychiatry 1979;134:382-9.

11. Logsdon RG, Gibbons LE, McCurry SM, Teri L. Quality of life in Alzheimer's disease: Patient and caregiver reports. Journal of Mental Health and Aging 1999;5:(1):21-33.

12. Folstein MF, Folstein SE, McHugh PR. A practical method for grading the cognitive state of patients for the clinician. Journal Psychiat Res 1975;12:189-98.

13. Ulstein I, Gordner V, Tonga J. Kordial studien. Manual for terapeuter. 2013.

14. Graneheim UH, Lundman B. Qualitative content analysis in nursing research:concepts, procedures an measures to achieve trustworthiness. Nurse education today 2004;24:105-12.

15. Tonga JB, Karlsøen BB, Arnevik EA, Werheid K, Korsnes MS, Ulstein ID. Challenges with manual-based multimodal psychotherapy for people with Alzheimer's disease: a case study. American Journal of Alzheimer's Disease \& Other Dementias 2016;31(4):311-7.

16. Antonovsky, A. Helsens mysterium. Den salutogene modellen. Oslo: Gyldendal Akademisk; 2012.

17. Orgeta V, Qasi A, Spector AE, Orrell M. Psychological treatments for depression and anxiety in dementia and mild cognitive impairment. The British Journal of Psychiatry 2015;207(4):293-8.

18. Engedal K, Haugen PK. Demens - Fakta og utfordringer. 5. utg. Tønsberg: Forlaget Aldring og helse; 2009.

19. Wetterberg P. Hukommelsesboken - Hvorfor vi husker godt og glemmer lett. Oslo: Gyldendal Norsk Forlag; 2005.

20. Ostwald SK, DugglebyW, Hepburn KW. The stress og dementia: View from the innside. American Journal of Alzheimer's Disease and Other Dementias; 2002;17(5):303-12.

21. Verkaik R, van Weert J, Francke AL. The effects of psychosocial methods on depressed, aggressive and apathetic behaviors of people with dementia: a systematic review. Int J Geriatric Psychiatry 2005;20(4):301-14.

22. Steeman E, Godderis J, Grypdonck M, De Bal N, De Casterlé BD. Living with dementia from the perspective of older people: Is it a positive story? Aging \& Mental Health 2007;11(2):119-30.

23. Næss S. Livskvalitet som psykisk velvære. Tidsskrift for Den norske legeforening 
2001;16(121):1940-4.

24. Fossland T, Thorsen K. Livshistorier i teori og praksis. Bergen: Fagbokforlaget; 2010.

25. Tranvåg O, Petersen KA, Nåden D. Crucial dimensions constituting dignity experience in persons living with dementia. Dementia 2016;15(4): 578-95.

26. Drageset I, Normann K, Elstad I. Familie og kontinuitet: Pårørende forteller om livsløpet til personer med demenssykdom. Nordisk Tidsskrift for Helseforskning 2012;8(1):3-19.

27. Hummelvoll JK. Helt - ikke stykkevis og delt. 7. utg.. Oslo: Gyldendal Akademisk; 2012.

28. Husband HJ. Diagnostic disclosure in dementia: An opportunity for intervention? International Journal of Geriatric Psychiatry 2000;15:544-7.

29. Bahro M, Silber E, Sunderland T. How do patients with Alzheimer's disease cope with their illness? - A clinical experience report. JAGS 1995;43:41-6.

30. Teri L. Behavioral treatment of depression in patients with dementia. Alzheimer Disease and Associated Disorders 1994;8(3):66-74. 